\title{
A Study of Thrombocytopenia in cases of Hepatitis C infection presenting at tertiary care hospital
}

\author{
MUHAMMAD ABDUL RAZIQ ${ }^{1}$, BUSHRA HUSSAIN², WAHHAJ MUNIR ${ }^{3}$, FAHAD QAISAR ${ }^{4}$ \\ ${ }^{1}$ Assistant Professor, Department of Physiology, Quaid-e-Azam Medical College, Bahawalpur \\ ${ }^{2}$ Assistant Professor, Department of Physiology, Sahiwal Medical College, Sahiwal \\ ${ }^{3}$ Final Year, Lahore Medical \& Dental College, Lahore \\ ${ }^{4}$ Senior Registrar Department of Medicine, Bahawal Victoria Hospital Bahawalpur \\ Correspondence to: Dr. Muhammad Abdul Raziq, Email:dr_maraziq@hotmail.com, Cell: 03006846778
}

\begin{abstract}
Aim: To determine the frequency of thrombocytopenia in hepatitis $c$ patients presenting at tertiary care hospital. Methods: This cross sectional study was conducted at Department of Physiology in collaboration with Department of Medicine, Bahawal Victoria Hospital, Bahawalpur from March 2020 to September 2020 over the period of 6 months. Total 150 of hepatitis C, either male or female having age 20-60 years were included. Thrombocytopenia was assessed in selected patients.

Results: In this study mean age of the patients was $44 \pm 12.38$ years. Out of 150 patients of hepatitis C, thrombocytopenia was present in $48(32 \%)$ patients. In age group 20-40 years, thrombocytopenia was found in $14(26.92 \%)$ patients while in age group 41-60 years, thrombocytopenia was seen in $34(34.69 \%)$ patients. No statistically significant association of thrombocytopenia with age group was detected with $p$ value 0.332 . Male patients were $93(62 \%)$ and female patients were $57(38 \%)$. Thrombocytopenia was found in $30(32.26 \%)$ male patients and in $18(31.58 \%)$ female patients. Association of thrombocytopenia with gender was not statistically significant with $p$ value 0.931 .

Conclusion: Results of present study revealed that higher proportion of hepatitis $C$ patients found with thrombocytopenia. Most of the patients belonged to $4^{\text {th }}$ and $5^{\text {th }}$ decade. Higher number of male patients were victim of hepatitis $C$ infection as compared to female patients. Most of the patients were obese. Higher number of patients were normotensive and non-diabetics.
\end{abstract}

Keywords: Hepatitis C, thrombocytopenia, cirrhosis, hepatocellular carcinoma

\section{INTRODUCTION}

Hepatitis C (HCV) is a viral infection which primarily affected the liver ${ }^{1}$. About 185 million population of the world is infected with HCV and tow third of these cases developed chronic liver disease $(C L D)^{2}$. In Pakistani population, about 10 million cases are reported with HCV infection with infection rate $2.2-14 \%{ }^{3}$. Thrombocytopenia is very common in cases of HCV and platelet count less than 150000 cell/ microliters are considered as thrombocytopenia ${ }^{4}$. The main role of platelets is maintaining normal homeostasis and vessel wall repair. ${ }^{5}$ Infectious diseases, massive blood loss, sequestration of platelets, increase in destruction or consumption of platelets, platelet production failure are the very common causes of thrombocytopenia ${ }^{5}$. Literate showed a strong association between HCV infections and development of thrombocytopenia, studies documented that about $64-76 \%$ cases suffering from fibrosis, cirrhosis, $\mathrm{HCV}$ infection and chronic infections showed manifestations of thrombocytopenia as compared to noncirrhotic $(6 \%)$ cases $^{6-7}$. This indicates that with increase in hepatocellular damage, prevalence and severity of thrombocytopenia increases. Mortality and increased risk of variceal bleeding are the major clinical complications of such cases. The mechanism leading to thrombocytopenia in $\mathrm{HCV}$ is complex and involves various host and viral factors ${ }^{8}$.

Received on 03-01-2021

Accepted on 14-04-2021
This study is planned to find out the frequency of Thrombocytopenia in cases of hepatitis C infection. Results of this study may help us for the early management of Thrombocytopenia. We may be able of to reduce the morbidity of hepatitis $C$ infection patients.

\section{OPERATIONAL DEFINITION}

Thrombocytopenia:Thrombocytopenia considered as platelet count $<150000$ cell/ microliters

Hepatitis C: The diagnosis of HCV status was done on ELISA and confirmed on PCR.

BMI was calculated by following formula:

$\mathbf{B M I}=$ weight in kilograms / height in meters ${ }^{2}$ and $\mathrm{BMI} \geq 30$ was taken as obese and $<30$ as non-obese.

\section{MATERIAL AND METHODS}

This cross-sectional study was conducted at Department of Physiology, Bahawal Victoria Hospital, Bahawalpur from March 2020 to September 2020 over the period of 6 months. Total 150 of hepatitis C, either male or female having age 20-60 years were included. All cases with hepatitis $\mathrm{B}$, patients with autoimmune disorders and patients with liver cirrhosis were excluded from the study. Study was approved by ethical committee and written informed consent was taken from every patient. History was taken of all the patients. Blood sample was taken from everypatient and send to laboratory for platelet count. Findings was noted on pre-designed proforma along with demographic profile of the patients. Height of the patients was measured by measuring tape and weight was taken by weighing machine to calculate the BMI. History of diabetes 
mellitus was also taken.Data was entered in computer software SPSS version 16. The quantitative variables of the study i.e. agewas presented as Mean \pm SD. The qualitative variables like gender anddiabetes mellitus were presented as frequencies and percentages. Pie chart was drawn for frequency of Thrombocytopenia. Stratification was done for age, gender and diabetes mellitus. Post stratification chi-square test was applied to see the effect of these on outcome variable. P.value $\leq 0.05$ was considered as significance.

\section{RESULTS}

In this study mean age of the patients was $44 \pm 12.38$ years. Out of 150 patients of hepatitis C, thrombocytopenia was present in $48(32 \%)$ patients (Fig. 1). Two age groups were created i.e. age group 20-40 years and age group 41-60 years. Age group 20-40 years consisted on 52(34.67\%) patients while age group 41-60 years was consisted on 98(65.33\%) patients. In age group 20-40 years, thrombocytopenia was found in $14(26.92 \%)$ patients while in age group 41-60 years, thrombocytopenia was seen in $34(34.69 \%)$ patients. No statistically significant association of thrombocytopenia with age group was detected with $p$ value 0.332 (Table 1).

Male patients were 93(62\%) and female patients were $57(38 \%)$. Thrombocytopenia was found in $30(32.26 \%)$ male patients and in $18(31.58 \%)$ female patients. Association of thrombocytopenia with gender was not statistically significant with p value 0.931 (Table 2$)$.

Obese patients were $87(58 \%)$ while non-obese patients were $63(42 \%)$. Thrombocytopenia was seen in 27 $(31.03 \%)$ obese patients while in $21(33.33 \%)$ non-obese patients. Insignificant association between thrombocytopenia and obesity was detected with $p$ value 0.786 (Table 3).

Total 56(37.33\%) patients were hypertensive, and thrombocytopenia was found in $16(28.57 \%)$ patients. Normotensive patients were 94(62.67\%) and thrombocytopenia was found in $32(34.04 \%)$ patients. Statistically insignificant association between thrombocytopenia and hypertension was noted with $p$ value 0.487 . (Table 4)Total $47(31.33 \%)$ patients were diabetics, and $103(68.67 \%)$ patients were non-diabetics. Thrombocytopenia was found in $13(27.66 \%)$ diabetics and in $35(33.98 \%)$ non-diabetics. No association of thrombocytopenia with diabetic status was found with $p$ value 0.441 (Table 5).

Fig. 1: Frequency of thrombocytopenia

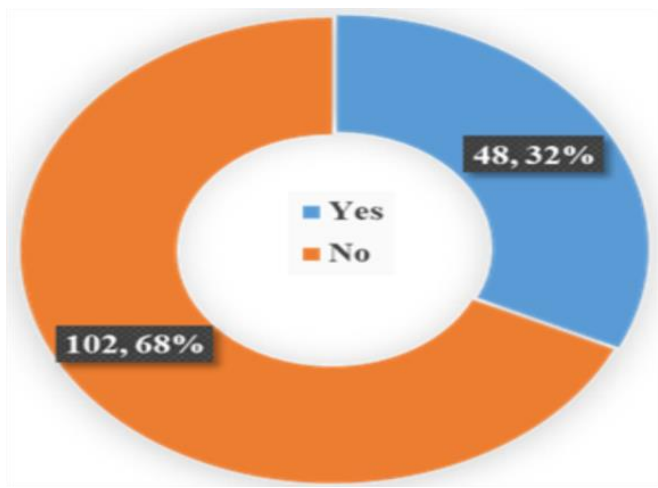

Table 1: Stratification for age

\begin{tabular}{|l|c|c|l|l|}
\hline \multirow{2}{*}{$\begin{array}{l}\text { Age } \\
\text { group }\end{array}$} & \multicolumn{2}{|c|}{ Thrombocytopenia } & \multirow{2}{*}{ Total } & \multirow{2}{*}{ P value } \\
\cline { 2 - 3 } & Yes & No & & \\
\hline $20-40$ & $14(26.92)$ & $38(73.08)$ & $52(34.67)$ & \multirow{2}{*}{0.332} \\
\hline $41-60$ & $34(34.69)$ & $64(65.31)$ & $98(65.33)$ & \\
\hline Total & $48(32)$ & $102(68)$ & 150 & \\
\hline
\end{tabular}

Table 2: Stratification for gender

\begin{tabular}{|c|c|c|c|c|}
\hline \multirow{2}{*}{ Gender } & \multicolumn{2}{|c|}{ Thrombocytopenia } & \multirow{2}{*}{ Total } & \multirow{2}{*}{$\begin{array}{l}P \\
\text { value }\end{array}$} \\
\hline & Yes & No & & \\
\hline Male & $30(32.26)$ & $63(67.74)$ & $93(62)$ & \multirow{3}{*}{0.931} \\
\hline Female & $18(31.58)$ & $39(68.42)$ & $57(38)$ & \\
\hline Total & $48(32)$ & $102(68)$ & 150 & \\
\hline
\end{tabular}

Table 3: Stratification for obesity

\begin{tabular}{|l|c|c|l|l|}
\hline \multirow{2}{*}{ Obesity } & \multicolumn{2}{|c|}{ Thrombocytopenia } & \multirow{2}{*}{ Total } & \multirow{2}{*}{ P value } \\
\cline { 2 - 3 } & Yes & No & & \\
\hline Obese & $27(31.03)$ & $60(68.97)$ & $87(58)$ & \multirow{2}{*}{0.786} \\
\hline Non-obese & $21(33.33)$ & $42(66.67)$ & $63(42)$ & \\
\hline Total & $48(32)$ & $102(68)$ & 150 & \\
\hline
\end{tabular}

Table 4: Stratification for hypertension

\begin{tabular}{|l|c|c|l|l|}
\hline \multirow{2}{*}{ Hypertension } & \multicolumn{2}{|c|}{ Thrombocytopenia } & \multirow{2}{*}{ Total } & \multirow{2}{\text{P}}{ value } \\
\cline { 2 - 3 } & Yes & No & & \\
\hline Hypertensive & $16(28.57)$ & $40(71.43)$ & $56(37.33)$ & \\
\hline Normotensive & $32(34.04)$ & $62(65.96)$ & $94(62.67)$ & \multirow{2}{*}{0.487} \\
\hline Total & $48(32)$ & $102(68)$ & 150 & \\
\hline
\end{tabular}

Table 5: Stratification for diabetes mellitus

\begin{tabular}{|l|c|c|l|l|}
\hline \multirow{2}{*}{$\begin{array}{l}\text { Diabetes } \\
\text { Mellitus }\end{array}$} & \multicolumn{2}{|c|}{ Thrombocytopenia } & \multirow{2}{*}{ Total } & \multirow{2}{*}{ P value } \\
\cline { 2 - 3 } & Yes & No & & \\
\hline Diabetics & $13(27.66)$ & $34(72.34)$ & $47(31.33)$ & \multirow{2}{*}{0.441} \\
\hline Non-diabetics & $35(33.98)$ & $68(66.02)$ & $103(68.67)$ & \\
\hline Total & $48(32)$ & $102(68)$ & 150 & \\
\hline
\end{tabular}

\section{DISCUSSION}

Hepatitis C virus (HCV) is consideredtobe the main etiological factor for chronic liver disease and accounts for about $70-75 \%$ cases of chronic hepatitis and $15-20 \%$ cases of cirrhosis and hepatocellular carcinoma. ${ }^{9}$ Viral hepatitis is highly endemic in Pakistan. Pakistan carries one of the world's highest burdens of chronic hepatitis and mortality due to liver failure and hepatocellular carcinomas. Although, prevalence of and risk factors for hepatitis $B$ and hepatitis $C$ are not exactly available, a weighted average of $\mathrm{HCV}$ prevalence was $3.0 \%{ }^{10}$. Thrombocytopenia, is a common complication in cases of CLD, that has been observed in about $76 \%$ of the cases ${ }^{11}$. The severity of thrombocytopenia can be variable either from being transient and isolated, to a severe, life threatening condition ${ }^{12}$. 
The purpose of present study was to find out the frequency of thrombocytopenia in cases of hepatitis $\mathrm{C}$ infection. In this study mean age of the patients was $44 \pm 12.38$ years. Out of 150 patients of hepatitis $C$, thrombocytopenia was present in $48(32 \%)$ patients. In one study by Nawaz et $\mathrm{al}^{13}$ mean age of patients was $47.25 \pm 11.52$ years and out of 141 patients, thrombocytopenia was present in $53 \%$ patients of hepatitis $\mathrm{C}$ infection. Findings of this study are higher than our study. In another study by Bano et $\mathrm{al}^{14}$ frequency of Thrombocytopenia was $43.3 \%$ in cases of hepatitis C. In study of Wang et $\mathrm{al}^{15}$ reported frequency of thrombocytopenia was $10.2 \%$ in cases of hepatitis C which is much lower than our study. Similarly study of Dodhy et $\mathrm{al}^{16}$ reported frequency of Thrombocytopenia in cases of hepatitis $\mathrm{C}$ as $25 \%$. In another study by Rahman et $\mathrm{al}^{17}$ Thrombocytopenia was found in $22 \%$ patients of hepatitis $\mathrm{C}$ infection. In another study by $A Z I Z$ et $\mathrm{al}^{18}$ found thrombocytopenia in $22.6 \%$ patients. Iman et $\mathrm{al}^{19}$ found thrombocytopenia in CLD cases due to HCV infection in $32.3 \%$ patients. In present study, in age group 20-40 years, thrombocytopenia was found in $14(26.92 \%)$ patients while in age group 41-60 years, thrombocytopenia was seen in $34(34.69 \%)$ patients. No statistically significant association of thrombocytopenia with age group was detected with $p$ value 0.332 . Male patients were 93(62\%) and female patients were $57(38 \%)$. Thrombocytopenia was found in $30(32.26 \%)$ male patients and in $18(31.58 \%)$ female patients. Association of thrombocytopenia with gender was not statistically significant with $p$ value 0.931 . Nawaz et $\mathrm{al}^{13}$ found thrombocytopenia in $57.3 \%$ male patients. In same study most of the cases belonged to $5^{\text {th }}$ decade. In one study ${ }^{20}$ thrombocytopenia was noted in $13.3 \%$ patients. In same study, males were more affected than females. In one study conducted in Peshawar reported insignificant association between thrombocytopenia and gender ${ }^{19}$.

\section{CONCLUSION}

Results of present study revealed that higher proportion of hepatitis $C$ patients found with thrombocytopenia. Most of the patients belonged to $4^{\text {th }}$ and $5^{\text {th }}$ decade. Higher number of male patients were victim of hepatitis $C$ infection as compared to female patients. Most of the patients were obese. Higher number of patients were normotensive and non-diabetics.

\section{REFERENCES}

1. Axley P, Ahmed Z, Ravi S, Singal AK. Hepatitis C virus and hepatocellular carcinoma: a narrative review. Journal of clinical and translational hepatology. 2018 Mar 28;6(1):79.

2. Jefferies M, Rauff B, Rashid H, Lam T, Rafiq S. Update on global epidemiology of viral hepatitis and preventive strategies. World journal of clinical cases. 2018 Nov 6;6(13):589.
3. Raja NS, Janjua KA. Epidemiology of hepatitis C virus infection in Pakistan. J Microbiol Immunol Infect. 2008; 41(1) $: 4-8$.

4. Afdhal N, McHutchison J, Brown R, Jacobson I, Manns M, Poordad F, et al. Thrombocytopenia associated with chronic liver disease. J Hepatol. 2008; 48(6) : 1000 -7.

5. Dahal S, Upadhyay S, Banjade R, Dhakal P, Khanal N, Bhatt VR. Thrombocytopenia in patients with chronic hepatitis $C$ virus infection. Mediterranean journal of hematology and infectious diseases. 2017;9(1).

6. Bashour FN, Teran JC, Mullen KD. Prevalence of peripheral blood cytopenias (hypersplenism) in patients with nonalcoholic chronic liver disease. Am J Gastroenterol. 2000; 95(10) : 2936 -9.

7. Giannini EG. Review article: thrombocytopenia in chronic liver disease and pharmacologic treatment options. Aliment PharmacolTher. 2006; 23(8) : 1055 -65.

8. Liangpunsakul S, Ulmer BJ, Chalasani N. Predictors and implications of severe hypersplenism in patients with cirrhosis. Am J Med Sci. 2003; 326(3) : 111 -6.

9. Mohammad N, Jan M.A. Frequency of hepatitis C in Buner, NWFP.J Coll Physicians Surg, 2005; 15: 11-4.

10. Chaudary IA, Samiullah, Khan SS, Masood R, Sardar MA, Mallhi AA. Seroprevalance of hepatitis B and C among healthy blood donors at Fauji foundation hospital Rawalpindi. Pak J Med Sci, 2007; 23: 64-67.

11. Afdhal N, McHutchinson J, Brown R, Jacobson I, Manns M, Poordad F, et al. Thrombocytopenia associated with chronic liver disease. J Hepatol, 2008; 48: 1000-7.

12. Adilson A, Marilza CM, Olivia MM, Carlos BM, Marareti O, Rosane $\mathrm{O}$, et al. Hepatitis C virus associated thrombocytopenia: a controlled prospective virological study. Ann Hematol; 2004; 83: 434-40.

13. Nawaz Z, Aurangzeb M, Imran K, Rasheed T, Alam MT, Jaffery MF, Khero S, Masroor M. Frequency of thrombocytopenia; patients with chronic hepatitis $\mathrm{C}$ infection. Professional Med J 2014;21(4): 684-690.

14. Bano S, Qureshi J, Raza A, Zafar Hashmi K. Thrombocytopenia as a clinical manifestation of hepatitis C among patients with a positive Anti-HCV test. International Journal of Infection. 2016 Jul 1;3(3).

15. Wang CS, Yao WJ, Wang ST, Chang TT, Chou P. Strong association of hepatitis $\mathrm{C}$ virus (HCV) infection and thrombocytopenia: implications from a survey of a community with hyperendemic HCV infection. Clinical infectious diseases. 2004 Sep 15;39(6):790-6.

16. Dodhy MA, Zafar H, Mujtaba A. Thrombocytopenia a presenting feature of Hepatitis C. Ann Pak Inst Med Sci. 2010;6(3):148-51.

17. Rahman S, Rahman S, Khan S, Ahmad N, Rahman N Frequency of thrombocytopenia in hepatitis c patients. J Med Sci 2019; 27: (3) 190-193.

18. AZIZ M, KHAN S. Frequency of thrombocytopenia in chronic active hepatitis c patients-a hindrance in treatment. Biomedica. $2014 \mathrm{Jul} ; 30(3): 1$.

19. Iman NU, Khan $\mathrm{H}$. Thrombocytopenia in chronic liver disease due to hepatitis C virus. Rawal Medical Journal. 2009;34(1):72-4.

20. Behnava B, Alavian S, Asl MA. The Prevalence of Thrombocytopenia in Patients with Chronic Hepatitis B and C. Hep Mon. 2006; 6 (2): 67-9. 